\title{
COVID-19 presenting with diarrhea in a heart transplant patient
}

\author{
Kalp nakilli bir hastada ishal ile seyreden COVID-19
}

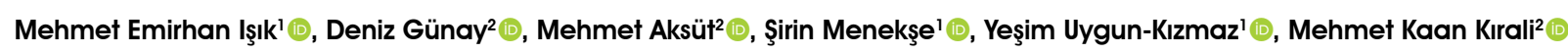 \\ 'Department of Infectious Diseases and Clinical Microbiology, Koşuyolu Yüksek Ihtisas Training and Research Hospital, Istanbul, Turkey \\ ${ }^{2}$ Department of Cardiovascular Surgery, Koşuyolu Yüksek Ihtisas Training and Research Hospital, Istanbul, Turkey
}

\begin{abstract}
A 55-year-old man who underwent bicaval orthotopic heart transplantation nine months earlier presented with complaints of diarrhea and oliguria. Laboratory findings showed pancytopenia and an elevated creatinine level. Cyclosporine and mycophenolate mofetil were discontinued, and the patient received only everolimus. As he was immunosuppressed and had atypical symptoms during the COVID-19 pandemic, reverse transcriptase-polymerase chain reaction testing was performed, which yielded a positive result. Treatment with hydroxychloroquine and favipiravir were initiated. Although the patient suffered from acute renal failure, his condition showed an improvement after hydration plus a five-day antiviral treatment and, then, treatment was stopped. His COVID-19 test was negative after 10 days of follow-up and treatment, and he was discharged with cyclosporin and mycophenolate mofetil.
\end{abstract}

Keywords: COVID-19, diarrhea, favipiravir, hydroxychloroquine.

Novel coronavirus-2019 (COVID-19) caused by severe acute respiratory syndrome - coronavirus 2 (SARS-CoV-2), which first emerged in Wuhan, China in December 2019, affected the whole world within a very short period, with more than 10 million individuals being infected by the end of June 2020 . Several factors including underlying heart diseases (hypertension, ischemic heart disease), respiratory diseases, diabetes, and advanced age have been proposed to play an important role in COVID-19-related mortality. ${ }^{[1]}$ Patients with immunodeficiency disorders or who receive immunosuppressive drugs have been also reported to be at risk. ${ }^{[2]}$

\section{$\ddot{O} Z$}

Dokuz ay önce bikaval ortotopik kalp nakli yapılan 55 yaşında erkek hasta, ishal ve oligüri şikayetleri ile başvurdu. Laboratuvar bulgularında pansitopeni ve kreatinin düzeylerinde artış izlendi. Siklosporin ve mikofenolat mofetil sonlandırıld 1 ve hastaya sadece everolimus verildi.

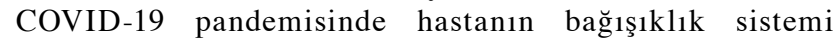
baskılanmış ve atipik semptomları olduğu için, revers transkriptaz polimeraz zincir reaksiyonu testi yapıldı ve sonuç pozitif saptand. Hidroksiklorokin ve favipiravir tedavisi başlandı. Akut böbrek yetmezliği de olan hastanın durumunda hidrasyon ve beş günlük antiviral tedavi sonrasında iyileşme görüldü ve tedavi sonlandırıldı. On günlük takip ve tedavi sonrasında COVID-19 testi negatif olan hasta, siklosporin ve mikofenolat mofetil ile taburcu edildi.

Anahtar sözcükler: COVID-19, ishal, favipiravir, hidroksiklorokin.

In this article, we present a 55-year-old COVID-19-positive male patient who underwent previous heart transplantation and was receiving immunosuppressive treatment.

\section{CASE REPORT}

A 55-year-old man who underwent bicaval orthotopic heart transplantation for dilated cardiomyopathy in July 2019 and was followed at the outpatient clinic for nine months without any problem presented to the heart transplant outpatient clinic with a five-day history of diarrhea, inability to urinate for one day, and mild edema. He had watery

\footnotetext{
Received: July 02, 2020 Accepted: August 31, 2020 Published online: January 13, 2021

Correspondence: Mehmet Emirhan Işık, MD. Koşuyolu Yüksek İhtisas Eğitim ve Araştırma Hastanesi, Enfeksiyon Hastalıkları ve Klinik Mikrobiyoloji Kliniği, 34865 Kartal, İstanbul, Türkiye. Tel: +90505 - 2711861 e-mail: emirhan82@gmail.com 
diarrhea two or three times a day, dark green in color, accompanied by abdominal pain which subsided after defecation. The patient was clinically well, with a body temperature of $36.7^{\circ} \mathrm{C}$, a respiratory rate of 14 breaths $/ \mathrm{min}$, an arterial blood pressure of $120 / 70 \mathrm{mmHg}$, and a heart rate of $86 \mathrm{bpm}$. Oxygen saturation was $98 \%$ on pulse oximetry at room air. On physical examination, the abdomen was soft with no tenderness, rebound tenderness or guarding, but he had pretibial edema. Laboratory examination revealed pancytopenia (white blood cell count $2.1 / \mathrm{mm}^{3}$, lymphocyte count $0.4 / \mathrm{mm}^{3}$, monocyte count $0.2 / \mathrm{mm}^{3}$, hemoglobin $8.2 \mathrm{~g} / \mathrm{dL}$, and platelet count $80 / \mathrm{mm}^{3}$ ). Other laboratory tests were within normal limits. On biochemical analysis for renal function, the urea was $67 \mathrm{mg} / \mathrm{dL}$, the creatinine was $3.24 \mathrm{mg} / \mathrm{dL}$, lactate dehydrogenase level was higher than 1.5 times the upper limit of normal (379 U/L). The C-reactive protein value was 6.14 (range, 0 to 3.1$) \mathrm{mg} / \mathrm{L}$. The cyclosporine level was $229 \mathrm{ng} / \mathrm{mL}$ and the everolimus level was $10.7 \mathrm{ng} / \mathrm{mL}$. Chest X-ray findings were unremarkable. Microscopic examination of the stool specimen revealed rare leukocytes, no parasites, and no growth in the culture. The patient whose kidney function was normal at previous follow-ups was hospitalized for further investigation and treatment for acute renal failure caused by diarrhea and pancytopenia. As the patient had high blood levels of immunosuppressants, cyclosporine and mycophenolate mofetil (MMF) were discontinued and the dose of everolimus was tapered off. The patient continued treatment with acetylsalicylic acid $100 \mathrm{mg} / \mathrm{day}$, atorvastatin $40 \mathrm{mg} / \mathrm{day}$, and metoprolol $50 \mathrm{mg} /$ day. Acute renal failure was suspected to be caused by a pre-renal cause, and hydration was initiated.

Although the patient had no respiratory symptoms, a thoracic computed tomography (CT) was performed due to pandemic, as the symptoms were mild. Although there was no typical involvement suggesting COVID-19, minimal nodular ground-glass opacity was observed in the upper lobe of the left lung, which was not present on the previous thoracic CT images. Despite the absence of symptoms suggestive of COVID-19 other than diarrhea, a nasopharyngeal swab specimen was collected. The reverse transcriptase-polymerase chain reaction (RT-PCR) testing of the nasopharyngeal swab specimen was positive for COVID-19. The patient received antiviral treatment with favipiravir at a loading dose of $1,600 \mathrm{mg}$ twice daily and a maintenance dose of $600 \mathrm{mg}$ twice daily plus hydroxychloroquine at a loading dose of $400 \mathrm{mg}$ twice daily and a maintenance dose of $200 \mathrm{mg}$ twice daily. Anticoagulant treatment was initiated with the prophylaxis dose. Daily electrocardiogram was taken and QTc was monitored for the side effects of hydroxychloroquine. Thoracic CT showed neither regression nor progression, and his diarrhea resolved and the patient became asymptomatic after five days of antiviral treatment. On Day 10, he had normal laboratory values, except for anemia. The patient received only everolimus as the immunosuppressive treatment during hospitalization. Control echocardiography showed no findings of transplant rejection. On Day 10, the cyclosporine level was $50.4 \mathrm{ng} / \mathrm{mL}$. His treatment was designed as cyclosporine $50 \mathrm{mg}$ twice daily and MMF $250 \mathrm{mg} / \mathrm{day}$. A repeat RT-PCR test of a nasopharyngeal swab specimen was negative. The patient was discharged on Day 12 without any symptoms. A written informed consent was obtained from the patient.

\section{DISCUSSION}

The COVID-19 pandemic heavily affected individuals with chronic diseases with higher mortality rates. ${ }^{[1]}$ Viral diseases have a more severe course in immunosuppressed individuals than in normal population, particularly in patients undergoing solid organ transplantation. ${ }^{[3,4]}$ In addition, a variety of clinical presentation was reported in a similar patient group, and no specific reason was predicted. To date, no link between different immunosuppressive treatment protocols and disease severity has been identified.$^{[2]}$

Of the two heart transplant recipients reported by Li et al., ${ }^{[5]}$ from China, where the pandemic started, one experienced the disease with mild symptoms, while the other had more severe symptoms. Of the two patients with heart transplantation reported by Holzhauser et al., ${ }^{[6]}$ one experienced COVID-19 more severe and died, while the other received treatment with only hydroxychloroquine and discharged home. In our case, we administered hydroxychloroquine and favipiravir and the patient was discharged uneventfully. Of note, initiation of anticoagulant therapy is recommended due to the tendency to thrombosis in COVID-19 patients. ${ }^{[7]}$

In Spain, Fernández-Ruiz et al. ${ }^{[4]}$ reported 18 patients with solid organ transplantation of whom four were heart transplant recipients, and that the most common complaint was fever $(83.3 \%)$. Pereira et al. ${ }^{[2]}$ shared their first three-week data in New York City and reported their experience with 90 patients with solid organ transplantation, including nine heart transplants and one heart-kidney transplant. The most common 
complaint was diarrhea (31\%), apart from fever and respiratory symptoms. Review of the literature revealed that symptoms of gastrointestinal system were also frequent in COVID-19-positive patients, and symptoms such as diarrhea, nausea, and abdominal pain were more common than COVID-19-negative patients. ${ }^{[8]}$ Our patient experienced typical COVID-19 symptoms; however, he had diarrhea, with no additional complaints at follow-up.

The PCR negativity seems to require a longer duration in patients with diarrhea. ${ }^{[9]}$ In our case, the patient had a positive RT-PCR test result, and diarrhea and abdominal pain resolved dramatically with the treatment and RT-PCR negativity was detected on Day 10. Pereira et al., ${ }^{[2]}$ suggested that immunosuppressed patients might have atypical symptoms due to impaired immune response and, therefore, routine screening should be performed in patients with solid organ transplants. In our routine practice during pandemic, we perform RT-PCR and thoracic CT examinations when necessary in this patient group at our institution. Although our case had no respiratory complaints, thoracic CT images were suggestive of COVID-19.

In conclusion, solid organ transplant recipients should be observed more closely than other patients in the current pandemic period, polymerase chain reaction testing should be performed in the presence of a possible clinical suspicion, and thoracic computed tomography should be performed, whenever necessary. Even if the polymerase chain reaction assay yields a negative result, treatment should be started in the early period, if thoracic computed tomography suggests infection and if COVID-19 is suspected clinically. In addition, it should be kept in mind that, apart from common symptoms, those of gastrointestinal system, such as diarrhea, abdominal pain, and nausea may be clinically more relevant and patients should be followed closely. It appears to be useful to initiate immunosuppressive treatment, considering the patient's clinical condition, until specific data are obtained in solid organ transplant recipients. Further studies would provide more accurate data regarding whether cytokine storm syndrome, which is responsible for the clinical deterioration of patients, is less common in immunosuppressed patients.

\section{Declaration of conflicting interests}

The authors declared no conflicts of interest with respect to the authorship and/or publication of this article.

\section{Funding}

The authors received no financial support for the research and/or authorship of this article.

\section{REFERENCES}

1. Guan WJ, Ni ZY, Hu Y, Liang WH, Ou CQ, He JX, et al. Clinical Characteristics of Coronavirus Disease 2019 in China. N Engl J Med 2020;382:1708-20.

2. Pereira MR, Mohan S, Cohen DJ, Husain SA, Dube GK, Ratner LE, et al. COVID-19 in solid organ transplant recipients: Initial report from the US epicenter. Am J Transplant 2020;20:1800-8.

3. Latif F, Farr MA, Clerkin KJ, Habal MV, Takeda K, Naka Y, Restaino S, Sayer G, Uriel N. Characteristics and Outcomes of Recipients of Heart Transplant With Coronavirus Disease 2019. JAMA Cardiol 2020:e202159.

4. Fernández-Ruiz M, Andrés A, Loinaz C, Delgado JF, LópezMedrano F, San Juan R, et al. COVID-19 in solid organ transplant recipients: A single-center case series from Spain. Am J Transplant 2020;20:1849-58.

5. Li F, Cai J, Dong N. First cases of COVID-19 in heart transplantation from China. J Heart Lung Transplant 2020;39:496-7.

6. Holzhauser L, Lourenco L, Sarswat N, Kim G, Chung B, Nguyen AB. Early experience of COVID-19 in 2 heart transplant recipients: Case reports and review of treatment options. Am J Transplant 2020;20:2916-22.

7. Tang N, Bai H, Chen X, Gong J, Li D, Sun Z. Anticoagulant treatment is associated with decreased mortality in severe coronavirus disease 2019 patients with coagulopathy. J Thromb Haemost 2020;18:1094-9.

8. Chen A, Agarwal A, Ravindran N, To C, Zhang T, Thuluvath PJ. Are Gastrointestinal Symptoms Specific for Coronavirus 2019 Infection? A Prospective Case-Control Study From the United States. Gastroenterology 2020;159:1161-3.e2.

9. Wei XS, Wang X, Niu YR, Ye LL, Peng WB, Wang ZH, et al. Diarrhea Is Associated With Prolonged Symptoms and Viral Carriage in Corona Virus Disease 2019. Clin Gastroenterol Hepatol 2020;18:1753-9.e2. 